\title{
EHMTI-0269. The idiopathic intracranial hypertension without papilloedema counterfeits the migrainous headache in clinical presentation
}

\author{
S Ljubisavljevic ${ }^{1 *}$, J Zidverc-Trajkovic ${ }^{2}$ \\ From 4th European Headache and Migraine Trust International Congress: EHMTIC 2014 \\ Copenhagen, Denmark. 18-21 September 2014
}

\section{Introduction}

Idiopathic intracranial hypertension (IIH) is a pathological state defined as an increase of intracranial pressure in the absence of a causative pathological process.

\section{Aim}

To evaluate the clinical features of the patients with IIH diagnosed in our Headache Ambulances according to the current knowledge of this disorder.

\section{Method}

In the retrospective and cross-sectional analysis of 3550 patients we present 18 newly diagnosed IIH patients, 15 women and 3 men, aged from 18 to 51, with obtained values of cerebrospinal fluid pressure between 220 and $680 \mathrm{~mm}$ of water. The symptoms of IIH clinical presentation have been headache, reported by $94 \%$ of patients without optic nerve papilloedema (PE) noted in $30 \%$ of them.

\section{Results}

The obtained results confirmed the presence of headache features that are included in criteria for headache attributed with IIH in patients with PE. On the other side, it is worth to note, that in patients without PE majority of them $(80 \%)$, had "migrainous" features of headache and accompanying symptoms.

\section{Conclusion}

We assume that a misdiagnosis of "primary" chronic migraine might be possible in patients without $\mathrm{PE}$ who may in fact suffer from a headache attributed to IIH

${ }^{1}$ Clinic for Neurology, Clinical center Nis, Nis, Serbia

Full list of author information is available at the end of the article according to currently used ICHD criteria. It seems that the headache profile of IIH is not pathognomonic as it sometimes mimics the primary headaches. We could conclude that some chronic migraine patients refractory for treatment might be patients with $\mathrm{IIH}$.

No conflict of interest.

\section{Authors' details}

${ }^{1}$ Clinic for Neurology, Clinical center Nis, Nis, Serbia. ${ }^{2}$ Clinic for Neurology, Clinical center Serbia, Belgrade, Serbia.

Published: 18 September 2014

doi:10.1186/1129-2377-15-S1-C37

Cite this article as: Ljubisavljevic and Zidverc-Trajkovic: EHMTI-0269. The idiopathic intracranial hypertension without papilloedema counterfeits the migrainous headache in clinical presentation. The Journal of Headache and Pain 2014 15(Suppl 1):C37.

Submit your manuscript to a SpringerOpen ${ }^{\odot}$ journal and benefit from:

- Convenient online submission

- Rigorous peer review

- Immediate publication on acceptance

- Open access: articles freely available online

- High visibility within the field

- Retaining the copyright to your article

Submit your next manuscript at $\boldsymbol{s p r i n g e r o p e n . c o m ~}$ (c) 2014 Ljubisavljevic and Zidverc-Trajkovic; licensee Springer. This is an Open Access article distributed under the terms of the Creative Commons Attribution License (http://creativecommons.org/licenses/by/2.0), which permits unrestricted use, distribution, and reproduction in any medium, provided the original work is properly cited. 